\title{
Pengukuran Capability Level Kualitas Layanan E-Government Kabupaten Pamekasan Menggunakan Framework COBIT 5.0
}

\author{
Measurement of Capability Level Of E-Government on Services Quality In Pamekasan
} District Using COBIT 5.0 Framework

\author{
Diterima: \\ 15 Januari 2019 \\ Revisi: \\ 2 Februari 2019 \\ Terbit Online: \\ 12 April 2019
}

\author{
${ }^{1}$ Aang Kisnu Darmawan, ${ }^{2}$ Arisandi Dwiharto \\ ${ }^{1}$ Prodi Sistem Informasi, Universitas Islam Madura \\ ${ }^{2}$ Prodi Teknik Informatika, Universitas Islam Madura \\ 1,2 Pamekasan, Indonesia \\ E-mail:1'ak.darmawan@gmail.com,2arisandidw@gmail.com
}

\begin{abstract}
Abstrak-Penelitian ini bertujuan untuk melakukan audit dan evaluasi terhadap layanan eGovernment Dispendukcapil Kabupaten Pamekasan pada Domain EDM dan APO. Metode yang digunakan adalah Framework COBIT.5, sebuah framework dalam mengukur kematangan tatakelola sistem informasi yang dikeluarkan oleh ISACA tahun 2012. Audit dilakukan di Kantor Dispendukcapil Kabupaten Pamekasan dan mengambil sampel Layanan e-Government di 4 Kecamatan dan 12 Kelurahan maupun Desa yang dianggap cukup representatif untuk dilakukan audit. Hasil penelitian menunjukkan bahwa Secara keseluruhan hasil audit capability level layanan TIK Dispendukcapil kabupaten Pamekasan berada pada level 3 (Establish) dengan nilai indeks capability level pada domain EDM 2,78 (establish) dan APO 2,50 (established). Temuan dilapangan menunjukkan bahwa proses bisnis dalam tatakelola TIK layanan e-Government ditingkat kecamatan, kelurahan maupun desa menunjukkan berada pada level 0 (incomplete) yang berarti bahwa hampir tidak ada sama sekali proses tata kelola layanan TIK ditingkatan tersebut. Saran dan rekomendasi yang bisa dilakukan adalah perlu kewenangan yang lebih banyak pada tatakelola ditingkat kecamatan, desa maupun kelurahan dengan menambahkan SDM yang kompeten dalam bidang TIK untuk memberikan layanan e-Governnment yang lebih baik.
\end{abstract}

Kata Kunci- e-Government, Capability Level, COBIT 5.0

\begin{abstract}
This study aims to conduct an audit and evaluation of the Pamekasan District eGovernment Dispute Settlement services on EDM and APO Domains. The method used is the COBIT Framework.5, a framework for measuring information system governance maturity issued by ISACA in 2012. The audit was conducted at the Pamekasan District Dispendukcapil Office and took samples of eGovernment Services in 4 Districts and 12 Districts considered quite representative to be audited.The results showed that overall the results of the audit capability level of ICT services at Pamekasan district Dispendukcapil were at level 3 (Establish) with capability level index values in establish and 2.O (established) EDM domains. Field findings show that business processes in ICT management of egovernment services at the sub-district, village levels show that they are at level 0 (incomplete), which means that there is almost no process of governance of ICT services at that level. Suggestions and recommendations that can be made are more authority is needed at the sub-district and village level by adding competent human resources in the ICT field to provide better e-Government services.
\end{abstract}

Keywords-e-Government, Capability Level, COBIT 5.0

INTENSIF: Jurnal Ilmiah Penelitian dan Penerapan Teknologi Sistem Informasi 
INTENSIF, Vol.3 No.2 August 2019

ISSN: 2580-409X (Print) / 2549-6824 (Online)

DOI: https://doi.org/10.29407/intensif.v3i2.12659

\section{PENDAHULUAN}

Instruksi Presiden No.3 tahun 2003 tentang kebijakan dan strategi penerapan pengembangan e-Government, menuntut Pemerintah untuk mampu menerapkan TIK dalam penerapan dan pengembangan e-Government [1][2]. E-Government adalah proses pemanfaatan TIK dalam menjalankan sistem pemerintahan yang efisien dan transparan dengan tujuan perbaikan administrasi pemerintahan pada semua jajaran dan upaya percepatan Reformasi pada Birokrasi Pemerintah [3]. Penerapan e-Government memberikan kesempatan bagi pemerintah untuk meningkatkan kualitas efisiensi, peningkatan partisipasi masyarakat dan layanan-layanan yang update terhadap kebutuhan dan masyarakata yang selalu dinamis. Pelayanan pemerintah diharapkan akan berjalan secara transparan, akuntabel dan dapat menghindarkan dari bentukbentuk penyimpangan agar dapat memberikan pelayanan secara lebih efektif dan efisien. [4][5] .

Kabupaten Pamekasan menghadapi berbagai kesulitan dalam menerapkan e-Government sebagaimana juga yang dialami oleh banyak Pemerintahan Daerah yang lain. Perencanaan pengembangan $e$-Government belum pernah dilakukan secara integral dan komprehensif dengan melibatkan semua pihak, instansi dan stakeholder yang terkait penerapan e-Government. Hal ini tentu menjadi kendala untuk mewujudkan Visi Kabupaten Pamekasan menjadi Kota Digital/Cyber City. Perlu penerapan tatakelola layanan TIK yang baik menuju Good Governance yang transparan, akuntabel dan efektif[6][7]. Control of Objective and Technology Related (COBIT 5) adalah sebuah framework dalam tatakelola TIK (IT Governance Framework) versi terbaru yang dikeluarkan oleh ISACA, sebuah lembaga Audit tingkat dunia tahun 2012 [8].

COBIT 5 menyediakan kerangka kerja yang komprehensif yang dapat membantu perusahaan atau institusi untuk mencapai tujuannya dalam hal tata kelola dan manajemen teknologi informasi. Prinsip dalam framework COBIT 5 adalah dengan menciptakan yang optimal dari TIK dengan menjaga keseimbangan antara manfaat TIK dan mengoptimalkan tingkat resiko dan penggunakan sumberdaya informasi[9][10]. COBIT 5 terdiri dari 5 domain utama yang terbagi dengan total sebanyak 37 proses bisnis dalam tatakelola TI. domain tersebut adalah domain Evaluate, Direct and Monitor (EDM); Domain Align, Plan and Organize (APO); Domain Build, Acquire and Implement (BAI); domain Deliver, Service and Support (DSS dan domain Monitor, Evaluate and Assess (MEA)[11][12].

Tujuan Penelitian ini adalah melakukan audit dan evaluasi terhadap tatakelola layanan TIK di Dispendukcapil Kabupaten Pamekasan menggunakan framework COBIT 5.0. Dengan penelitian ini dihasilkan sebuah nilai Capability Level, Analisis Kesenjangan dan sebuah rekomendasi Konsep dan Implementasi dalam Layanan Teknologi Informasi dan E-Government di Dispendukcapil kabupaten Pamekasan menggunakan Framework COBIT 5.0. 


\section{METODE PENELITIAN}

E-Government merupakan pemanfaatan TIK dibidang pemerintah. Instruksi Presiden Republik Indonesia no. 3 Tahun mengenai Kebijakan Nasional dan Strategi Pengembangan $e$ Government menegaskan pemerintah diharapkan dapat menciptakan peningkatan kualitas pelayanan publik yang efisien dan efektif [6][13]. Dalam pengembangan e-Government terdapat empat jenis layanan yaitu layanan Government to Government (G2G), Government to Business $(G 2 B)$, Government to Consumers (G2C) dan Government to Employees (G2E)[14]. Jenis layanan dapat dilihat pada gambar 1 .

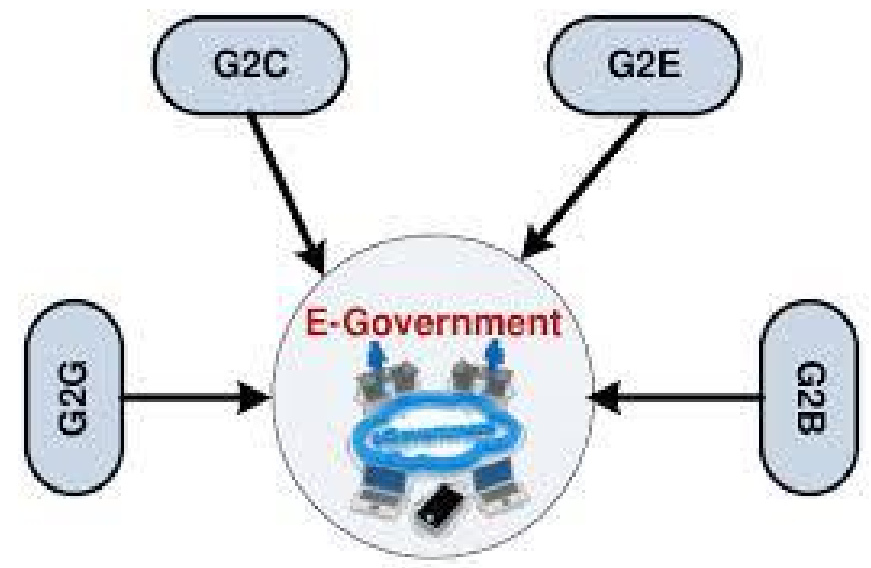

Gambar 1. JENIS LAYANAN E-GOVERNMENT

Control. Objectives for Information and Related Technology (COBIT 5.0) adalah sebuah kerangka kerja untuk mengukur kualitas sebuah tatakelola teknologi informasi yang membantu agar lebih fokus terhadap nilai strategis penerapan teknologi informasi (IT strategic value) serta memastikan penerapan TI dapat mendukung pencapaian visi dan misi perusahaan atau institusi [9][15]. Kerangka kerja COBIT 5, yang terdiri atas 5 prinsip utama dan dilengkapi dengan 7 enabler. COBIT 5 menyelarasakan antara lima prinsip yang memungkinkan organisasi enterprise untuk membangun sebuah framework tata kelola dan manajemen yang efektif berdasarkan pendekatan holistik dari tujuh enabler yang disediakan sehingga dapat mengoptimalisasikan investasi bidang teknologi dan informasi sekaligus memberikkan keuntungan kepada stakeholder. Pada gambar 2 kita bisa melihat lima prinsip COBIT 5 dan enablers pada gambar 3 [16]. 


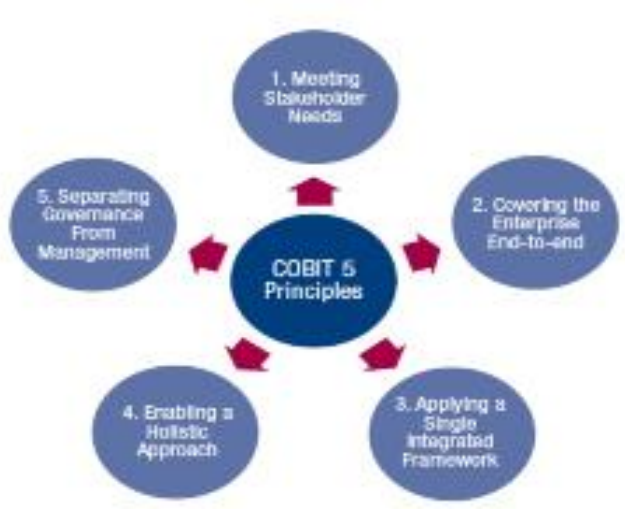

Gambar 2. PRINSIP UTAMA COBIT 5.0

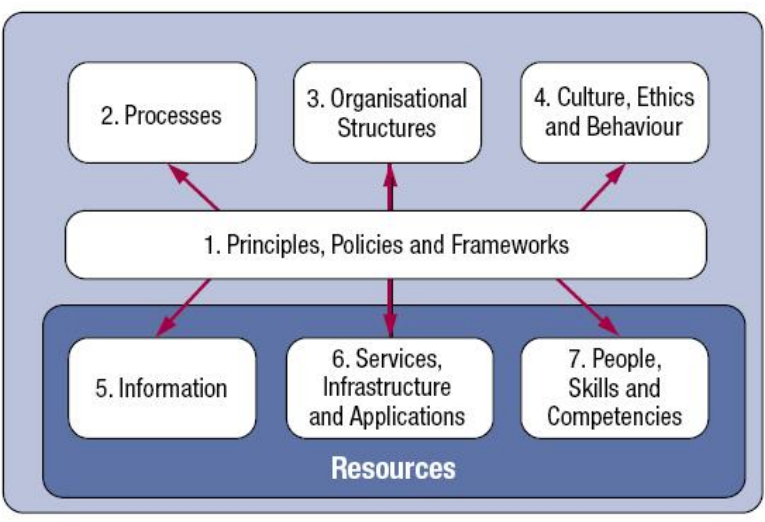

Gambar 3. TUJuH ENABLERS COBIT 5.0

Pada kerangka kerja COBIT 5.0 terdapat 6(enam) level proses tingkatan Capability Level yaitu :

a. Level 0 (Incomplete), tidak dilaksanakan atau sedikit/tidak ada bukti sistematis atas tujuan proses.

b. Level 1 (Performed), telah mencapai tujuan proses.

c. Level 2 (Managed), diimplementasikan dalam model yang terkelola (direncanakan, dimonitor, dan disesuaikan) dengan produk kerja yang tepat, dikendalikan, dan dipelihara.

d. Level 3 (Established), terimplementasi sesuai standar yang ada.

e. Level 4 (Predictable), beroperasi sesuai batas yang ditentukan untuk mencapai hasil proses.

Level 5 (Optimized), terus ditingkatkan untuk memenuhi kodisi terkini yang relevan dan diarahkan pada tujuan bisnis. Model capability level seperti digambarkan pada gambar 4.

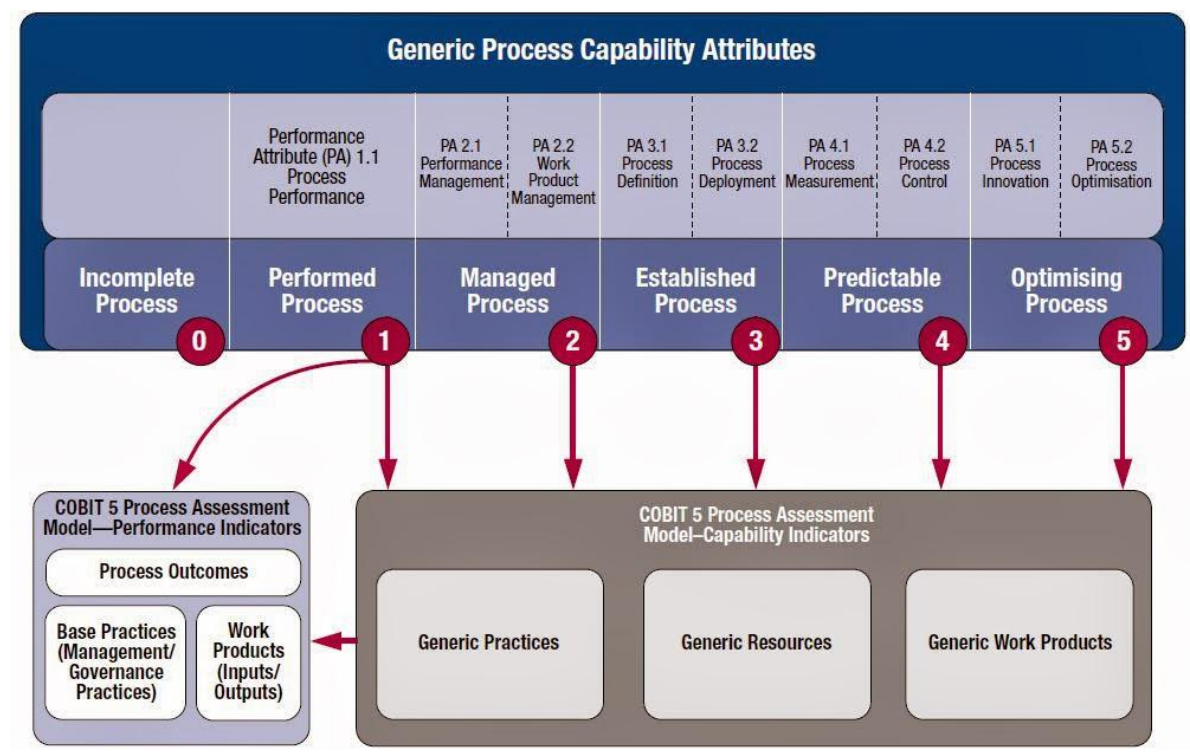

Gambar 4. Model CAPABILITY LEVEL COBIT 5.0 
Penelitian ini telah dilakukan proses evaluasi dan Audit Capability Level terhadap domain Evaluate, Direct and Monitor (EDM); Domain Align dan Domain Plan and Organize (APO). Pelaksanakan kegiatan penelitian menggunakan metode penelitian yang diberikan dalam diagram alir pada gambar 5 .

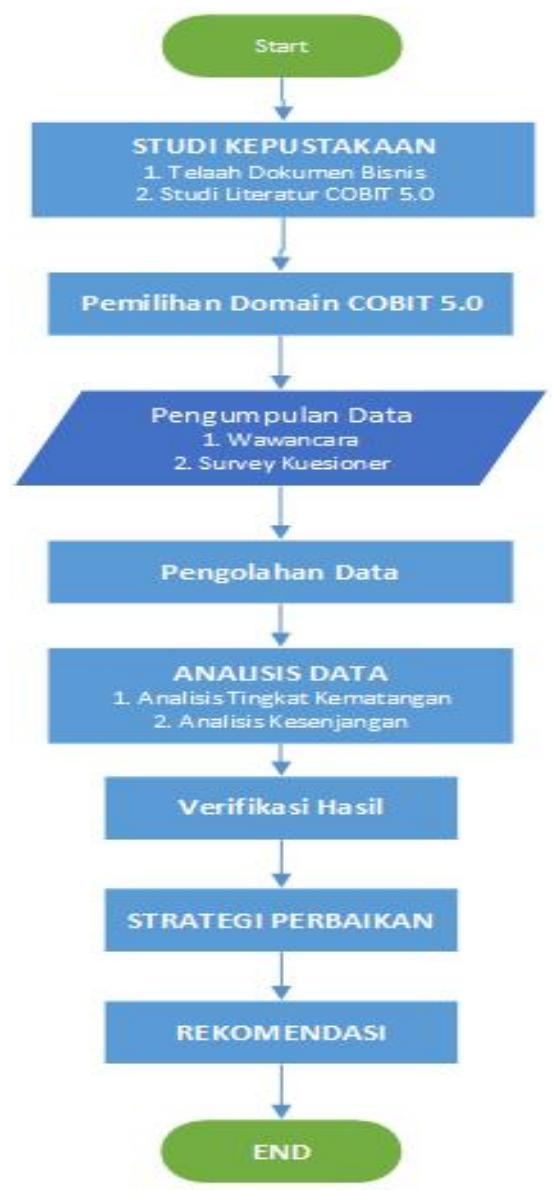

Gambar 5. TAHAPAN PENELITIAN COBIT 5

Penjelasan dari tahapan metodologi penelitian Framework COBIT 5.0 diatas adalah sebagai berikut :

1. Objek Penelitian dilakukan pada Dinas Kependudukan dan Catatan Sipil Kabupaten Pamekasan, 4 kecamatan dan 12 Desa/kelurahan yang dipilih dan dianggap cukup mewakili layanan E-Government di Kabupaten Pamekasan.

2. Studi Kepustakaan Diharapkan mampu menggali semua informasi yang terkait dengan penelitian, baik permasalahan yang diteliti dan objek yang menjadi tujuan penelitian.

3. Pemilihan Domain COBIT 5 Pemilihan dilakukan berdasarkan pemilihan domain yang difungsikan akan menyita waktu lama. 
INTENSIF, Vol.3 No.2 August 2019

ISSN: 2580-409X (Print) / 2549-6824 (Online)

DOI: https://doi.org/10.29407/intensif.v3i2.12659

4. Pengumpulan Data Proses pengumpulan data berupa observasi, kuesioner, dan wawancara. Observasi dilakukan dengan cara mengamati langsung kegiatan yang dilakukan. Observasi dilakukan di Dinas Kependudukan dan Catatan Sipil Kabupaten Pamekasan dan 4 kecamatan dan 12 Desa/kelurahan yang dipilih. Kuesioner dilakukan dengan 2 jenis kuesioner yaitu kuesioner kesadaran pengelolaan (management awareness) dan kuesioner tingkat kematangan (maturity level). Responden yang dipilih berjumlah 5 orang yaitu : a. Kepala Dinas Dispendukcapil/Camat/Lurah b. Kepala Bidang Pelayanan IT c. Kepala Bidang Administrasi d. Kepala Bidang Kependudukan e. Staff IT bidang E-ktp d. Staff IT pelayanan TI.

5. Wawancara dilakukan untuk memperoleh informasi berupa tanya jawab dengan responden sebagai pendukung hasil kuesioner. Wawancara digunakan untuk mendapatkan informasi lebih lengkap mengenai masalah yang diteliti yang tidak ada pada kuesioner.

6. Pengolahan Data-data yang terkait dengan penelitian dikumpulkan, dengan analisis kapabilitas yang bersifat kuantitatif diperoleh dari assessment secara langsung ke pihak terkait menggunakan checklist yang diadopsi dari assessment tool template COBIT 5 dari ISACA. Langkah tersebut dilakukan untuk mempermudah menerjemahkan dan mengartikan bukti yang dibutuhkan.

7. Analisis Data Proses analisis data dilakukan setelah pengolahan data, analisa data yang dilakukan terdiri dari analisis kesadaraan pengelolaan (management awareness), analisa kapabilitas saat ini (as is), tingkat kapabilitas yang diharapkan (to be), dan analisis kesenjangan (gap analysis). Untuk menghitung total nilai Capability dalam COBIT 5 digunakan rumus sebagai berikut :

Capability Level Compliance value (a) $=\frac{\text { Sum of otatement complisnce values }}{\text { Wumber of maturity level atatgment }}$

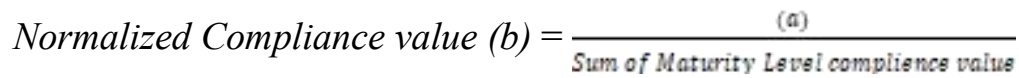

Summary Capability Level $=$ (b) $x$ Level of Capability

Total Capability level $=$ Sum of Summary Capability level

8. Verifikasi Hasil Hasil dari analisis kapabilitas kemudian dilakukan berupa proses verifikasi terhadap fakta-fakta yang ada.

9. Strategi Perbaikan Setelah dilakukan proses verifikasi, kemudian dilakukan proses strategi perbaikan berdasarkan data.

10. Rekomendasi Setelah melakukan proses strategi perbaikan kemudian dilakukan rekomendasi berdasarkan domain yang terkait dari COBIT 5 
INTENSIF, Vol.3 No.2 August 2019

ISSN: 2580-409X (Print) / 2549-6824 (Online)

DOI: https://doi.org/10.29407/intensif.v3i2.12659

\section{HASIL DAN PEMBAHASAN}

Pengukuran Capability Level, Expected Capability Level dan Gap Analysis Domain Evaluate, Direct, Monitor (EDM) Layanan TIK Dispendukcapil Kabupaten Pamekasan pada tabel 1. Hasil grafik dapat dilihat pada gambar 6 .

Tabel 1. Hasil Pengukuran CaPability LeVEL, EXPECTED CAPability LeVEl DaN GAP ANALYSIS DOMAIN EVALUATE, DIRECT, MONITOR (EDM)

\begin{tabular}{|c|c|c|c|c|}
\hline PROSES & $\begin{array}{c}\text { INDEX } \\
C A P A B I \\
L I T Y \\
\end{array}$ & $\begin{array}{l}\text { LEVEL/ } \\
T A R G E T\end{array}$ & $G A P$ & REKOMENDASI \\
\hline $\begin{array}{l}\text { EDM-1: Menentukan } \\
\text { dan Mempertahankan } \\
\text { Kerangka Tata Kelola TI }\end{array}$ & 2,40 & 2 (Managed)/4 & 1,60 & $\begin{array}{l}\text { Perlu dilakukan penyusunan } \\
\text { Kerangka kerja untuk proses layanan } \\
\text { tatakelola TI yang komprehensif dan } \\
\text { terintegrasi dengan baik }\end{array}$ \\
\hline $\begin{array}{l}\text { EDM-2: Memastikan } \\
\text { Pengoptimalan } \\
\text { Nilai/Prinsip }\end{array}$ & 2,70 & $\begin{array}{l}3 \\
\text { (Established) } \\
4\end{array}$ & 1,30 & $\begin{array}{l}\text { Perlu penguatan, repertisi dan } \\
\text { implementasi Nilai dan prinsip- } \\
\text { prinsip Layanan TI yang sudah ada } \\
\text { secara konsisten }\end{array}$ \\
\hline $\begin{array}{l}\text { EDM-3: Memastikan } \\
\text { Pengoptimalan Risiko }\end{array}$ & 3,10 & $\begin{array}{l}3 \\
(\text { Established }) / \\
4\end{array}$ & 0,90 & $\begin{array}{l}\text { Perlu dilakukan penguatan } \\
\text { manajemen resiko yang terintegrasi } \\
\text { dengan baik untuk meminimalisasi } \\
\text { gangguan layanan TIK }\end{array}$ \\
\hline $\begin{array}{l}\text { EDM-4: Memastikan } \\
\text { Pengoptimalan Sumber } \\
\text { Daya }\end{array}$ & 3,40 & $\begin{array}{c}3 \\
\text { (Established/4 }\end{array}$ & 0,60 & $\begin{array}{l}\text { Perlu dilakukan penambahan personil } \\
\text { dan manajemen SDM bidang TIK } \\
\text { yang lebih baik untuk mendukung } \\
\text { layanan yang prima }\end{array}$ \\
\hline $\begin{array}{l}\text { EDM-5: Memastikan } \\
\text { Transparansi } \\
\text { Stakeholder }\end{array}$ & 2,30 & 2 (Managed)/4 & 1,70 & $\begin{array}{l}\text { Perlu dibentuk mekanisme dalam } \\
\text { rangka penguatan transparansi } \\
\text { tatakelola layanan TIK, misal perlu } \\
\text { diadakan rapat triwulan stakeholder } \\
\text { dan pengelola layanan TIK }\end{array}$ \\
\hline $\begin{array}{l}\text { Indeks Total Domain } \\
\text { EDM }\end{array}$ & 2,78 & $\begin{array}{c}\text { 3(Established) } \\
/ 4\end{array}$ & 1,22 & $\begin{array}{l}\text { Perlu dilakukan penguatan setiap } \\
\text { Subdomain Tata kelola TIK yang } \\
\text { cukup signifikan }\end{array}$ \\
\hline
\end{tabular}

INTENSIF: Jurnal Ilmiah Penelitian dan Penerapan Teknologi Sistem Informasi 
INTENSIF, Vol.3 No.2 August 2019

ISSN: 2580-409X (Print) / 2549-6824 (Online)

DOI: https://doi.org/10.29407/intensif.v3i2.12659

\section{Capability Level Domain EDM \\ Layanan TI Dispendukcapil Kab.Pamekasan}

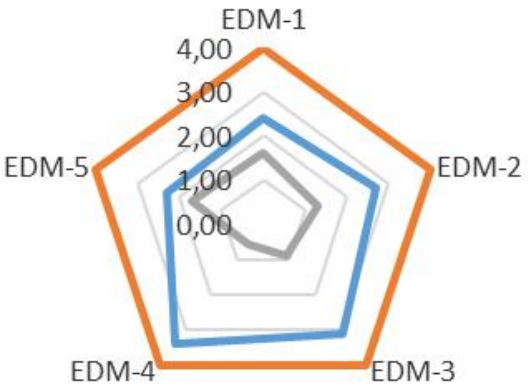

Gambar 6. SPIDERCHART HASIL PENGUKURAN CAPABILITY LEVEL, EXPECTED CAPABILITY LEVEL DAN GAP ANALYSIS DOMAIN EVALUATE, DIRECT, MONITOR (EDM)

Pengukuran Capability Level, Expected Capability Level dan Gap Analysis Domain Align, Plan dan Organize (APO) Layanan TIK Dispendukcapil Kabupaten Pamekasan tabel 2. Hasil grafik dapat dilihat pada gambar 7 .

Tabel 2. Hasil Pengukuran CAPABILITy LeVEL, EXPECTED CAPABILITY LEVEL DAN GAP ANALYSIS DOMAIN EVALUATE, DIRECT, MONITOR (EDM)

\begin{tabular}{|c|c|c|c|c|}
\hline PROSES & $\begin{array}{c}\text { INDEX } \\
\text { CAPABI } \\
\text { LITY } \\
\end{array}$ & $\begin{array}{l}\text { LEVEL/ } \\
T A R G E T\end{array}$ & $\boldsymbol{G A P}$ & REKOMENDASI \\
\hline $\begin{array}{l}\text { APO-1: Menentukan } \\
\text { Kerangka Manajemen } \\
\text { untuk Layanan TI }\end{array}$ & 2,23 & $\begin{array}{c}2 \\
(\text { Managed) }\end{array}$ & 1,77 & $\begin{array}{l}\text { Perlu dibuat dokumen SOP dan standard } \\
\text { Tata kelola layanan TIK yang melibatkan } \\
\text { stakeholder, pengelola layanan TIK dan } \\
\text { pihak masyarakat pengguna }\end{array}$ \\
\hline $\begin{array}{l}\text { APO-2: Manajemen } \\
\text { Strategi }\end{array}$ & 2,31 & $\begin{array}{c}2 \\
(\text { Managed) } \\
\quad / 4\end{array}$ & 1,69 & $\begin{array}{l}\text { Perlu dibuat dokumen SOP dan standard } \\
\text { strategi pelayanan dan tata kelola } \\
\text { layanan TIK sebagai pedoman Strategi } \\
\text { dan Tata Kelola layanan TIK }\end{array}$ \\
\hline $\begin{array}{l}\text { APO-3: Manajemen } \\
\text { Arsitektur Sistem } \\
\text { Institusi }\end{array}$ & 2,38 & $\begin{array}{c}2 \\
\text { (Managed) } \\
14 \\
\end{array}$ & 1,62 & $\begin{array}{l}\text { Perlu dilakukan penambahan dan } \\
\text { penguatan Arsitektur Sistem Institusi } \\
\text { untuk peningkatan layanan TIK }\end{array}$ \\
\hline $\begin{array}{l}\text { APO -4: Manajemen } \\
\text { Inovasi }\end{array}$ & 2,54 & $\begin{array}{l}3 \\
\text { (Establishe } \\
\text { d) } / 4\end{array}$ & 1,46 & $\begin{array}{l}\text { Perlu dilakukan inovasi dan update } \\
\text { kualitas layanan TIK dari aspek } \\
\text { teknologi yang digunakan baik hardware, } \\
\text { softwarenya }\end{array}$ \\
\hline $\begin{array}{l}\text { APO -5: Manajemen } \\
\text { Portofolio }\end{array}$ & 2,73 & $\begin{array}{c}3 \\
\text { (Establishe } \\
\text { d) } / 4\end{array}$ & 1,27 & $\begin{array}{l}\text { Perlu dilakukan pencatatan portofolio } \\
\text { kegiatan, ganggunan dan rekomendasi } \\
\text { perbaikan }\end{array}$ \\
\hline $\begin{array}{l}\text { APO-6: Manajemen } \\
\text { Anggaran dan Biaya }\end{array}$ & 2,42 & $\begin{array}{c}2 \\
\text { (Managed) } \\
/ 4\end{array}$ & 1,58 & $\begin{array}{l}\text { Perlu dilakukan pencatatan, penyusunan } \\
\text { RAB dan evaluasi terhadap anggaran } \\
\text { biaya dengan lebih baik }\end{array}$ \\
\hline
\end{tabular}


INTENSIF, Vol.3 No.2 August 2019

ISSN: 2580-409X (Print) / 2549-6824 (Online)

DOI: https://doi.org/10.29407/intensif.v3i2.12659

Tabel 2. Hasil Pengukuran CAPABILITY LEVEL, EXPECTED CAPABILITY LEVEL DAN GAP ANALYSIS DOMAIN EVALUATE, DIRECT, MONITOR (EDM) [LANJUTAN]

\begin{tabular}{|c|c|c|c|c|}
\hline PROSES & $\begin{array}{c}\text { INDEX } \\
\text { CAPABI } \\
\text { LITY } \\
\end{array}$ & $\begin{array}{l}\text { LEVEL/ } \\
\text { TARGET }\end{array}$ & $\boldsymbol{G A P}$ & REKOMENDASI \\
\hline $\begin{array}{l}\text { APO-7: Manajemen } \\
\text { SDM }\end{array}$ & 2,08 & $\begin{array}{c}2 \\
\text { (Managed) } \\
/ 4\end{array}$ & 1,92 & $\begin{array}{l}\text { Perlu dilakukan penambahan personil } \\
\text { SDM bidan TIK untuk menunjang } \\
\text { peningkatan layanan TIK }\end{array}$ \\
\hline $\begin{array}{l}\text { APO-8: Manajemen } \\
\text { Relasi }\end{array}$ & 2,23 & $\begin{array}{c}2 \\
(\text { Managed }) \\
14\end{array}$ & 1,77 & $\begin{array}{l}\text { Perlu dibuat wadah untuk proses } \\
\text { komunikasi yang lebih baik antara } \\
\text { stakeholder, pengelola layanan TIK dan } \\
\text { masyarakat pengguna layanan TIK }\end{array}$ \\
\hline $\begin{array}{l}\text { APO-9: Manajemen } \\
\text { Komitmen Layanan }\end{array}$ & 2,77 & $\begin{array}{c}3 \\
\text { (Establishe } \\
\text { d) } / 4\end{array}$ & 1,23 & $\begin{array}{l}\text { Perlu dilakukan evaluasi secara kontinyu } \\
\text { dan berkala terhadap kualitas layanan } \\
\text { dan komitmen pengelola TIK }\end{array}$ \\
\hline $\begin{array}{l}\text { APO-10: Manajemen } \\
\text { Pemasok }\end{array}$ & 2,65 & $\begin{array}{c}3 \\
\text { (Establishe } \\
\text { d) } / 4\end{array}$ & 1,35 & $\begin{array}{l}\text { Perlu dilakukan komunikasi dan } \\
\text { koordinasi dengan pemasok dengan lebih } \\
\text { baik }\end{array}$ \\
\hline $\begin{array}{l}\text { APO-11: Manajemen } \\
\text { Kualitas }\end{array}$ & 2,85 & $\begin{array}{c}3 \\
\text { (Establishe } \\
\text { d) } / 4\end{array}$ & 1,15 & $\begin{array}{l}\text { Perlu dilakukan evaluasi secara kontinyu } \\
\text { dan berkala terhadap kualitas layanan } \\
\text { dan komitmen pengelola TIK }\end{array}$ \\
\hline $\begin{array}{l}\text { APO-12: Manajemen } \\
\text { Resiko }\end{array}$ & 2,69 & $\begin{array}{l}3 \\
\text { (Establishe } \\
\text { d) } / 4\end{array}$ & 1,31 & $\begin{array}{l}\text { Perlu dibuat dokumen untuk pencatatan, } \\
\text { perancangan dan evaluasi terhadap } \\
\text { resiko yang terjadi untuk meminimalisasi } \\
\text { resiko }\end{array}$ \\
\hline $\begin{array}{l}\text { APO-13: Manajemen } \\
\text { Keamanan Sistem }\end{array}$ & 2,62 & $\begin{array}{c}3 \\
\text { (Establishe } \\
\text { d) } / 4\end{array}$ & 1,38 & $\begin{array}{l}\text { Perlu dibuat SOP dan dokumen standard } \\
\text { keamanan sistem informasi layanan TIK }\end{array}$ \\
\hline Indeks Total & 2,50 & $\begin{array}{c}3 \\
(\text { Establish } \\
\text { ed) } / 4\end{array}$ & 1,50 & $\begin{array}{l}\text { Perlu dilakukan penguatan setiap } \\
\text { Subdomain Tata kelola TIK yang } \\
\text { cukup signifikan }\end{array}$ \\
\hline
\end{tabular}

Capability Level Domain APO

Layanan TI Dispendukcapil Kab.Pamekasan

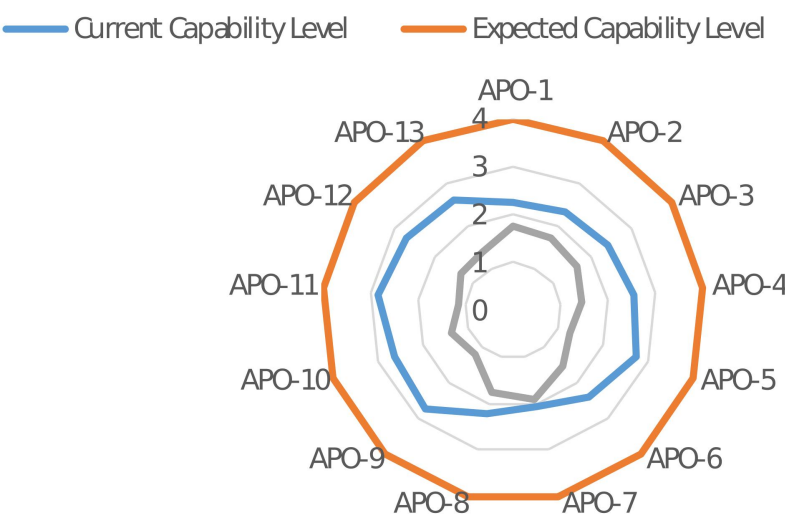

Gambar 7. SPIDERCHART HASIL PENGUKURAN CAPABILITY LEVEL, EXPECTED CAPABILITY LEVEL DAN GAP ANALYSIS DOMAIN EVALUATE, DIRECT, MONITOR (EDM)

INTENSIF: Jurnal Ilmiah Penelitian dan Penerapan Teknologi Sistem Informasi 
INTENSIF, Vol.3 No.2 August 2019

ISSN: 2580-409X (Print) / 2549-6824 (Online)

DOI: https://doi.org/10.29407/intensif.v3i2.12659

\section{KESIMPULAN DAN SARAN}

Secara keseluruhan hasil audit capability level layanan TIK Dispendukcapil kabupaten Pamekasan berada pada level 3 (Establish) yang artinya proses layanan TIK sudah terimplementasi sesuai standard layanan TIK yang ada. Dengan rincian dengan rincian domain EDM, indeks capability level 2,78 (establish), domain APO dengan indeks capability level 2,50 (established). Temuan dilapangan adalah bahwa proses bisnis dalam tatakelola TIK layanan $e$ government ditingkat kecamatan, kelurahan dan desa menunjukkan berada pada level 0 (incomplete) yang menyatakan bahwa hampir tidak ada sama sekali proses tata kelola layanan TIK ditingkatan tersebut. Saran dan rekomendasi yang bisa dilakukan adalah perlu kewenangan yang lebih banyak pada tatakelola ditingkat kecamatan, dan desa/kelurahan dengan menambahkan SDM yang kompeten dalam bidang TIK untuk memberikan layanan eGovernment yang lebih baik.

\section{UCAPAN TERIMAKASIH}

Terima kasih kami ucapkan kepada Kemristekdikti. Penelitian ini terselenggara dengan dana dari DRPM Kemristekdikti dengan Skema Penelitian Dosen Pemula (PDP) tahun anggaran 2018.

\section{DAFTAR PUSTAKA}

[1] C. Paper, D. Napitupulu, and U. B. Luhur, "Kajian Faktor Sukses Sistem Layanan Berbasis Elektronik ( E-Services ) di Lembaga Pemerintah Kajian Faktor Sukses Sistem Layanan Berbasis Elektronik," no. August, 2017.

[2] C. Paper, D. Napitupulu, A. Febri, A. Lembaga, and I. Pengetahuan, "ANALISA KUALITAS WEBSITE INTRA LIPI BERBASIS PENDEKATAN WEBQUAL DAN IMPORTANCE PERFORMANCE ANALYSIS: STUDI KASUS DI SATKER X," no. August, 2016.

[3] F. Masyhur, "IMPLEMENTASI STRATEGI E-GOVERNMENT KOTA PAREPARE MENGGUNAKAN MODEL CASSIDY DAN DIMENSI PEMERINGKATAN EGOVERNMENT INDONESIA (PeGI)," J. Penelit. Komun. dan Opini Publik, vol. 20, no. 2, pp. 111-122, 2016.

[4] N. Karniawati and R. Rahmadani, "ANALISIS KEBIJAKAN PENERAPAN EGOVERNMENT MELALUI SISTEM INFORMASI MANAJEMEN KEPEGAWAIAN (SIMPEG) (SUATU STUDI PADA BIRO KEPEGAWAIAN SEKRETARIAT DAERAH PROVINSI JAWA BARAT)," Maj. Ilm. UNIKOM Vol.7, vol. 7, no. 2, pp. 233-248, 2017.

[5] T. Muryanti, M. Pinilih, and D. Oktaviana, "EVALUASI SISTEM INFORMASI MANAJEMEN RUMAH SAKIT ( SIMRS ) PADA RSIA BUNDA ARIF PURWOKERTO MENGGUNAKAN FRAMEWORK COBIT 5," vol. 11, no. 2, pp. 59$75,2018$.

[6] S. F. S. G, "The Critical Success Factors Model for e-Government Implementation in Indonesia," 2017 Fifth Int. Conf. Inf. Commun. Technol., vol. 0, no. c, pp. 0-4, 2017.

[7] Z. Alreemy, V. Chang, R. Walters, and G. Wills, "International Journal of Information 
Management Critical success factors ( CSFs ) for information technology governance ( ITG )," Int. J. Inf. Manage., vol. 36, no. 6, pp. 907-916, 2016.

[8] F. A. Anza, D. I. Sensuse, and A. Ramadhan, "Developing E-Government Maturity Framework Based on COBIT 5 and Implementing in City Level : Case Study Depok City and South Tangerang City," Proceeding EECSI, no. September, pp. 19-21, 2017.

[9] H. M. Astuti, F. A. Muqtadiroh, E. Wahyu, and T. Darmaningrat, "ScienceDirect Risks Assessment of Information Technology Processes Based on COBIT 5 Framework : A Case Study of ITS Service Desk," Procedia Comput. Sci., vol. 124, pp. 569-576, 2018.

[10] G. Sabatini, "Information Technology Governance Assessment in Universitas Atma Jaya Yogyakarta using COBIT 5 Framework," Proceeding EECSI, no. September, pp. 19-21, 2017.

[11] M. A. Putri, I. Aknuranda, and W. F. Mahmudy, "Maturity Evaluation of Information Technology Governance in PT DEF Using Cobit 5 Framework," J. Inf. Technol. Comput. Sci., vol. 2, no. 1, pp. 19-27, 2017.

[12] F. A. Anza, D. I. Sensuse, and A. Ramadhan, "Developing E-Government Maturity Framework Based on COBIT 5 and Implementing in City Level : Case Study Depok City and South Tangerang City," Proc. EECSI, no. September, pp. 19-21, 2017.

[13] Y. Muflihah and T. D. Susanto, "FAKTOR YANG MEMPENGARUHI WARGA DAN PEMERINTAH DALAM ADOPSI E-GOVERNMENT: SEBUAH ULASAN SISTEMATIS," J. Teknol. Inf. dan Ilmu Komput., vol. 4, no. 4, pp. 304-310, 2017.

[14] F. Palijama, "Developing Modified PeGI Indicators for e- Government Ranking Method," Int. Conf. Inf. Technol. Inf. Syst. Electr. Eng. (ICITISEE), Yogyakarta, Indones., vol. 1, no. 1, pp. 169-173, 2016.

[15] N. Z. Firdaus, "Evaluasi Manajemen Risiko Teknologi Informasi Menggunakan COBIT 5 IT Risk ( Studi Kasus : PT . Petrokimia Gresik ),” J. Pengemb. Teknol. Inf. dan Ilmu Komput., vol. 2, no. 1, pp. 91-100, 2018.

[16] R. G. Mufti and Y. T. Mursityo, "Evaluasi Tata Kelola Sistem Keamanan Teknologi Informasi Menggunakan Framework COBIT 5 Fokus Proses APO13 dan DSS05 ( Studi Pada PT Martina Berto Tbk )," J. Pengemb. Teknol. Inf. dan Ilmu Komput., vol. 1, no. 12, pp. 1622-1631, 2017. 